\title{
WHY VALUES MATTER IN THE GLOBAL STRUGGLE FOR POWER. KEY IMPLICATIONS FOR EURO-ATLANTIC SECURITY
}

\author{
Cristina BOGZEANU, Ph.D., \\ Senior Researcher, Centre for Defence and Security Strategic Studies, \\ "Carol I" National Defence University, Bucharest, Romania. \\ E-mail: bogzeanu.cristina@unap.ro
}

\begin{abstract}
International environment becomes increasingly competitive and conflict prone. The present paper argues that political values subsumed to liberal democracy are an important component of the current global struggle for power and its purpose is to emphasize and argue the major importance of value-based cohesion for Euro-Atlantic actors, as well as the main challenges in this respect. In order to do so, the analysis is framed within the theories of power transition and security community as, together, they reflect both the manner in which values can act as a motivation for conflict and their function as a bond making the members of a security community able to pursue their interest in a conflicting international environment.
\end{abstract}

Keywords: power transition theory, security community, hybrid warfare, liberal democracy.

\section{Methodology}

Brexit, US president conditioning compliance with collective security principles on financial aspects, EU member states infringing on fundamental EU values, EU leaders not agreeing on the manner in which the EU defence shall evolve, NATO member state deciding to cooperate with the Russian Federation in developing military equipment despite de worsening relations between Moscow and Western actors are all recent instances of the fragmentation of Euro-Atlantic cohesion. All these have been considered a sign of international liberalism failure (Mearsheimer 2019) (Wright 2018). At the same time, international security environment tends to become increasingly unstable: tensed relations between great powers, the on-going hybrid aggression, failure of armament control regimes, Russia's aggressive posture in Wider Black Sea Region, prolonged regional conflicts, recurrent waves of migration determined by conflict, the increasingly close perspective of a post-pandemic economic and financial crisis, the continuous rise of world military expenditures.

It is a world which seems to be increasingly governed by the principles of realism, of rational actors pursuing their interests defined in terms of power in an anarchic world. The thesis of this paper is that political liberalism is still of high importance not only in the current days, but also in the coming ones. This paper is based on the results of a previous research undertaken within the Centre for Defence and Security Studies, which revealed the need to deepen the analysis of the negative implications of the fragmentation of Euro-Atlantic cohesion (Centre for Defence and Security Strategic Studies 2021).

The argumentation is framed in the power transition theory and security communities as their theoretical assumptions illustrate the connection between defending shared values cohesion of security communities - maintaining Euro-Atlantic actors' strategic relevance in the context of the sharpening geopolitical competition. Also, competition and conflict dynamics in international system is explained through power transition theory assumptions, emphasizing 
STRATEGIES XXI International Scientific Conference

The Complex and Dynamic Nature of the Security Environment

that one of the main motivations of dissension is anchored in the ideological area. Thus, it is brought to the fore the need keeping our security community cohesive as here lies one of the main targets within hybrid aggression.

Negative trends of liberal democracy shall be illustrated with relevant studies and indexes and framed in the analysis of current events in the international arena. This paper concludes that, despite the increasing insecurity in the international system which determines the proclivity for a realist perspective on international relations, Euro-Atlantic actors need to watch and struggle for defending their values, namely liberal democratic values, as an essential pre-condition for them to be able to cope with the challenges arising from an increasingly competitive and conflict prone international system.

\section{Specific of the current geopolitical competition}

Power transition theory addresses both structural and dynamic aspects of international relations, starting from the premise that political interests are the source of all disputes among international actors (Tammen, et al. 2000, 6). Thus, it builds a theoretical framework useful in explaining the competition between great powers as it takes into account not only principles of realism (international actors are rational and their action in the international arena is determined by interests defined in terms of power), but also aspects that could rather be framed in the paradigm of idealism or constructivism, such as the fact that states sharing the same values are more likely to form enduring alliances and security communities. Thus, the theory can explain the international dynamics both from the perspective of increasing competitiveness and conflict between great powers, and from the perspective of cooperation within the Euro-Atlantic community.

Power transition theory premises that the resources of power at the international level are scarce and are concentrated at the level of few, thus creating the basis of a hierarchical vision on the international system. At the top of the hierarchy is a state that has the status of a dominant power (not a hegemon). It ensures its preponderance in terms of power over other actors by managing the international system according to a series of rules that respond to its own national aspirations and those of its allies (Tammen, et al. 2000, 6-7). Ronald L. Tammen et. all argue that conflicts arise at the international level when a great power (not the dominant one) becomes dissatisfied with its international status, and its ability to project influence beyond its own borders increases exponentially (Tammen, et al. 2000, 9-10). Dissatisfied powers seek to change the international statu-quo because they do not consider it to be in line with their long-term expectations and interests. The motivations invoked can be extremely diverse ranging from historical, cultural, territorial, ideological aspects (Tammen, et al. 2000, 9). In the current international context, one of the aspects that differentiate the statu-quo states, on the one hand, and the revisionist ones, on the other, is the type of government - democratic in the first case, authoritarian in the second. Therefore, conflict between great powers today also has a strong ideological motivation. Hybrid aggression targeting Euro-Atlantic community's vulnerabilities in this respect is illustrative in this line of thought.

The challenge of US status as primus inter pares has been achieved through economic and political instruments, both by Moscow and in Beijing, in distinct forms. Both of them are in conflict with Western actors, especially the United States - China, mainly on the economic ground, and Russia on the background of the actions in Wider Black Sea Region (WBSR), of manner of relating to the security regimes in Europe, but also of the hybrid aggression directed against the actors from the Euro-Atlantic security community. For the United States, China is the main strategic rival, tensions between the two escalating during D. Trump's presidential term. This conflict also infers on Europe, where China has interests and economic influence, 
but also strengthens economic and political relations with states in the east or southeast of the continent, regions where not all countries are members of NATO and EU, but whose instability may affect the level of stability of European actors and, implicitly, the US. This is one of the reasons why, in EU's view, China is an "economic competitor in pursuit of technological leadership and a strategic rival that promotes alternative models of government" (European Commission and HR/VP 2019). The terms in which the EU refers to Beijing reflect the two dimensions of competition for power in this case - firstly, the economic one and, secondly, the political values-related one, as China takes opposite positions on the value system promoted and defended by the Euro-Atlantic community - liberal democracy ${ }^{1}$. It is, moreover, an area in which the official discourse of both sides tends towards inflexibility and even aggression, reflecting the dissatisfaction of Beijing with the international statu-quo.

At the same time, the actions of the Russian Federation have brought back the spectrum of military threat in Europe's security equation. Its central role in triggering and maintaining the Ukrainian crisis since 2014, aggressively pursuing its interests in WBSR and even in the Western Balkans, increasing military presence in WBSR, harnessing the "energy weapon" to promote regional interests, constantly opposing to the positions of Euro-Atlantic actors in managing regional crises, claiming new areas of interest (Arctic space) and even embarking on a race for space or for the prestige gained by medical resources (Sarcinschi, Competiția pentru vaccin și resurse medicale: o nouă fațetă a luptei pentru putere pe scena internațională 2020) are among the nuances that competition between the Russian Federation and the Euro-Atlantic community have known recently.

Russia's divide et impera strategy is one of the specific aspects of the conflicting relations with Western actors, a strategy also embraced by China recently. This is because one of the sources of power of the Euro-Atlantic community is the cohesion of NATO and the EU, but also because the Euro-Atlantic community already has a number of vulnerabilities in this direction, easily exploited by acts of hybrid aggression. Such actions are exemplified by interference in the electoral processes of EU and NATO member states and their neighbors, in particular by supporting extremist political formation (United States Senate 2018), constant, vehement and often aggressive contestation of the values promoted by them, etc. Thus, together with its military aggressiveness in European Eastern Neighbourhood, Russia's strategy has focused on contesting the values of liberal democracy (Barber, Foy and Barker 2019) and promoting apparently alternative values (traditional values, opposing to terrorism, neo-fascism, migration and the so-called "political correctness") (President of Russia 2013).

\section{Political values as domain for great powers' competition and conflict}

Also, power transition theory can provide a framework for explaining the relationship between international actors depending on the level of satisfaction with the statu-quo of the international system at a given time (Figure 1), thus providing a useful tool to assess the level of conflict potential between great power. When actors are satisfied and international rules are favourable to their own interests, they develop cooperative relationships, even going so far as to create security communities, stable alliances (NATO) or economic integration organizations (EU). We will consider the actors from the Euro-Atlantic space as exponents of an international state of affairs and of a set of rules that are challenged by the revisionist actors. China and the Russian Federation are considered the main resurgent powers, claiming the status of major world powers, as well as areas of strategic influence.

\footnotetext{
${ }^{1}$ See Beijing-Hong Kong relations, Taiwan relations, claiming sovereignty over areas of the South China Sea and the East China Sea, reaction to Western attempts to defend the rights of the Uighur minority (We Will Not Back Down under Sanctions, China warns the EU 2021).
} 


\begin{tabular}{|c|c|c|c|}
\hline $\begin{array}{c}\text { Actors' view on } \\
\text { world statu-quo }\end{array}$ & Satisfied - Satisfied & $\begin{array}{c}\text { Satisfied - } \\
\text { Dissatisfied }\end{array}$ & $\begin{array}{c}\text { Dissatisfied - } \\
\text { Dissatisfied }\end{array}$ \\
\hline Cooperation & $\begin{array}{c}\text { Security Community } \\
\text { Economic } \\
\text { Integration }\end{array}$ & $\begin{array}{c}\text { Collusive } \\
\text { improving } \\
\text { partnership }\end{array}$ \\
Non-cooperation & $\begin{array}{c}\text { Confrontational } \\
\text { competition }\end{array}$ & $\begin{array}{c}\text { Confrontational } \\
\text { competition }\end{array}$ & Hierarchical \\
reordering war & Escalating war \\
\hline
\end{tabular}

Figure 2: Joint Statu Quo Evaluation depending on the level of satisfaction in relation to the international status quo

Source: Ronald L. Tammen et al. all, 2000.

Joint statu-quo evaluation table explains the nature of the relations between actors depending on their degree of satisfaction with the current state of international system, with the rules governing the system in a given time. Satisfied actors, such as the US and its allies nowadays, establish relations of cooperation and build security communities and economic integration. NATO and EU picture the high institutionalization of this type of relation. In case of disagreement, satisfied actors verge towards confrontation competition. In our opinion, it is still another instance of cooperation within a security community, which is theoretically defined as "a transnational region, made up of sovereign states, whose populations maintain expectations based on peaceful change" (Adler and Barnett 1998, 30). Also, members resolve their conflicts other than by force, and is based on a number of shared values and meanings. Cooperation relations are set in various fields and its members have a number of common interests, usually anchored in the field of achieving a high degree of stability, security and prosperity. In other words, membership in a security community doesn't imply the absolute lack of conflict, but the approach of disagreement between members in ways other than confrontation.

Also relevant for the purpose of our paper is that these security communities know two forms of organization - "weakly connected", respectively "strongly connected" (Miroiu and Ungureanu 2006, 245). If the above definition applies to weakly connected security communities, a number of other features appear in the case of strongly connected communities. Thus, in order to have a strongly connected security community, it is necessary to meet the following conditions (Miroiu and Ungureanu 2006, 245-246):

a) sharing identities, values and meanings;

b) the actors that make it up develop direct relations in various fields;

c) is based on the mutual understanding of the interaction partners, which leads to the formulation of common interests, but also of mutual obligations.

Recent events reflect the fact that these characteristics, which form the basis of EuroAtlantic cohesion, are today facing multiple challenges both inside and outside the community. 
Joint Statu-Quo evaluation also explains the nature of the partnership between Russia and China in the context created after 2014, when Western actors imposed economic and diplomatic sanctions on Russia. Moscow-Beijing ties developed on these coordinates, thus limiting the effect of sanctions on Western actors, avoiding the situation of international isolation of Russia. The weight of this partnership increases if we consider that both are permanent members of the UN Security Council and both are in various forms in conflict with Western actors. This is why the partnership between the two countries has often been considered a "convenience" one (Ozawa 2019), meaning that they are open to cooperate when their interests converge, but without meeting the conditions for forming a security community. In this context, their interest in anchored on their aspiration of creating a multipolar world: "Both would like to see, and actively promote, the transition to a multipolar world with spheres of influence, one dominated by the US, China and Russia and where states, whether authoritarian or democratic, conduct their domestic and regional affairs independently of each other" (Ozawa 2019).

Thus, we may conclude that the current state of international system may be characterized through confrontational competition between statu-quo powers (US and its allies) and revisionist powers - China and Russia. Also, ideology, political values are one of the major domains where great power conflict happens. Ever since 2018, Freedom House warned that "the world's leading autocracies - Russia and China (...) are single-minded in their identification of democracy as a threat to their oppressive regimes, and they work relentlessly, with increasing sophistication, to undermine its institutions and cripple its principal advocates" (Abramowitz 2018). The same idea, but with reference to NATO, was resumed recently: "Political divergences within NATO are dangerous because they enable external actors, and in particular Russia and China, to exploit intra-Alliance differences and take advantage of individual Allies in ways that endanger their collective interests and security" (Reflection Group Appointed by the NATO Secretary General 2020, 16).

The current National Security Strategy of the Russian Federation states that the issue of moral leadership and the creation of an ideological basis for the future world order is becoming more urgent (Boyle 2021, 3). In China's strategic vision, strategic competition is presented not only in terms of rivalry between major powers, but also in the clash of different ideological systems (Office of the Secretary of Defence - China 2021, 1). Also, in NATO's terms, geopolitical competition supposes "the profusion and escalation of state-based rivalries and disputes over territory, resources, and values" (Reflection Group Appointed by the NATO Secretary General 2020, 16).

In this line of thought, we may conclude that political values are an area of disagreement between world's major powers. Also, as far as the Euro-Atlantic community is concerned, sharing the same vision on political values (in this case, liberal democracy) and laying them at the basis of their relations is key both in terms of security and stability and in terms of capacity of pursuing interests in a competitive global environment.

\section{Liberal democracy trends to watch and reverse}

The reason why this trend is a source of the most serious security threats is related to two major arguments:

- First of all, cohesion is the center of gravity of the Western power bloc, which has become a security community;

- Secondly, regardless of the level of analysis we are at, we identify challenges for this center of gravity of the Euro-Atlantic and European community, challenges that are mutually reinforcing. 
STRATEGIES XXI International Scientific Conference

The Complex and Dynamic Nature of the Security Environment

For the US, strategic partnership with European actors and membership in NATO (even if it bears a large part of the Alliance's financial burden) is one of the major sources of power in relation to revisionist powers such as the Russian Federation and China. Moreover, the importance of belonging to a strategic bloc is also highlighted by the fact that the powers that are not satisfied with the international statu quo cooperate with each other when the aim is to weaken or counter the power of the Western bloc. In addition, for the European states, the construction and functioning of the EU has brought benefits not only in economic terms, but also the way in which small states, with limited resources of power, get to play a substantial role in the international arena by their membership to NATO and the EU.

The anchoring in the theoretical framework of the security community is relevant because it brings to the fore that these actors need cohesion in order to have the capacity to act in a relevant way on the international arena. As their solidarity and cohesion is based on sharing the same values of liberal democracy, we can refer to them as centre of gravity. In this regard, the implications of the theory of power transition for the stability of alliances and the formation of security communities are illustrative. Thus, the level of stability of alliances derives from the similarity of the interests of the state actors that compose them and from the common vision on the statu quo at international level, which is the basis of cooperative relations between them (Tammen, et al. 2000, 13). Both organizations have at their basis fundamental liberal democratic values ${ }^{2}$.

This is the reason for which the decline of liberal democracy is one of the most serious challenges to be approached today as it is the source of major long-term threats to Euro-Atlantic security. At the beginning of 2020, Freedom House annual report warned about an unprecedented decline of democracy, emphasizing that the number of democracies is at its lowest in the last 25 years (Freedom House 2020). The conclusion of 2020 Democracy Index is similar goes in the same line (The Economist Intelligence Unit 2021), emphasizing that "only about half (49.4\%) of the world's population live in a democracy of some sort, and even fewer $(8.4 \%)$ reside in a "full democracy" (The Economist Intelligence Unit 2021, 3). Similarly, VDem report concludes that "the global decline during the past 10 years is steep and continues in 2020, especially in the Asia-Pacific region, Central Asia, Eastern Europe, and Latin America" (V-DEM 2021, 6). All these sources are showing the same trend of liberal democracy decline worldwide, a trend which has been amplified by the restrictive measures undertaken in the Covid-19 pandemic.

However, even on this background, Euro-Atlantic area is still the most democratic and safe one when compared to the rest of the world, there are two main peculiarities which we all shall consider warning signs. Firstly, there is the declining trend in terms of democratic quality and secondly, there is the net difference between Western Europe and North America, on the one hand, and, Eastern Europe, on the other, as the decline of liberal democracy in the latter is more steep (V-DEM 2021, 13). Hungary, Poland and Slovenia are experiencing the most substantial decline (V-DEM 2021, 18) (Freedom House 2021, 2). Thus, there arises a net risk of creating serious gaps within the Euro-Atlantic security community, difficult to manage and reduce as long as liberal democracy is on a declining trend ${ }^{3}$.

\footnotetext{
2 "They are determined to safeguard the freedom, common heritage and civilisation of their peoples, founded on the principles of democracy, individual liberty and the rule of law. They seek to promote stability and well-being in the North Atlantic area" (NATO 1949); "The Union is founded on the values of respect for human dignity, freedom, democracy, equality, the rule of law and respect for human rights, including the rights of persons belonging to minorities. These values are common to the Member States in a society in which pluralism, nondiscrimination, tolerance, justice, solidarity and equality between women and men prevail" (The European Union 2010, 17).

${ }^{3}$ For extended examples and analyses in this respect, see: (Bogzeanu 2020b)
} 
As mentioned before, the decline of democracies is not a recent trend, but it may have deeper implications under the impact of hybrid aggression. One of the peculiarities of hybrid aggression consists in the fact that, as far as Western states and societies are concerned, it doesn't not aim at occupying and controlling territories, but at disturbing their capacity to function properly (Lasconjarias 2017). Also, this type of aggression doesn't necessarily has in view to create new vulnerabilities, but to exploit and make the most of the ones already in place. In M. Galeotti's words, "a broad strategy of weakening the European Union and NATO, distancing Europe and the United States from each other, and generally creating a political and cultural environment more conducive for Moscow and its interests" (Galeotti 2017).

At the same time, the consistent history of this phenomenon, as well as the implications of various forms of hybrid aggression have made possible the development of a series of solutions at Euro-Atlantic level, opportunities to reduce threats and risks arising from the global tendency of becoming dominated by forms of government with undemocratic characteristics.

One of them is the concern for the development of the resilience of states and societies at NATO and EU level, with a focus on protecting democratic systems, as a solution for maintaining and strengthening cohesion at the level of the two organizations. Although, at first glance, it would have been expected that at the Alliance level, resilience would target governments' ability to function continuously, in crisis situations included, there is an initiative to set a Centre of Excellence for Democratic Resilience, which can be interpreted as a sign of the democratic values importance acknowledgement for the cohesion of the Alliance. The mission of this Centre would be to support allies, upon request, in strengthening the resilience of societies to withstand hostile actions coordinated by third parties on the proper functioning of democratic institutions and processes (Reflection Group Appointed by the NATO Secretary General 2020, 14).

Similarly, in the case of the EU the issue of the resilience of democracies goes beyond the text of the strategic documents (EU Global Strategy 2016), with many examples of measures taken in this direction. Among these, there are the introduction of a chapter dedicated to Cohesion, Resilience and Values in the Multiannual Financial Plan 2021-2027 (EU Council 2020) and the establishment of the Rule of Law Mechanism. Also in mid-2021, was adopted the European Democracy Action Plan (European Commission 2021), setting out specific measures to support the quality of democracy in European states in 3 major areas: elections free and fair, freedom of the press and misinformation.

Given the additional pressure on the degradation of the quality of democracy through direct and deliberate action, the development of a culture of security can be seen as part of efforts to strengthen the resilience of states and societies. In this sense, education in the spirit of developing the culture of security can create the basis for an informed report not only on the phenomena with security impact, but also on the skills and critical thinking necessary to discern the information to which we are exposed in each day.

\section{Conclusions}

In the current context of increasingly competitive international system, values, especially political ones, are used as motivation for conflict - main participants in the global struggle for power embrace different, even opposing values, praising the benefits of their own governance systems and considering the others flawed. This fact is also strongly supported by the conclusions of the studies on liberal democracy trends, acknowledging that the world is becoming less and less democratic and the states embracing autocracy or verging towards autocracy are more numerous with every year.

Also, there is a direct relation between shared political values (liberal democracy) Euro-Atlantic security community cohesion (centre of gravity) - the ability to act cohesively 
STRATEGIES XXI International Scientific Conference

The Complex and Dynamic Nature of the Security Environment

within the competitive and conflict prone international system. This centre of gravity which is currently flawed by internal forces and trends is under attack within the hybrid confrontation between the West and the revisionist powers.

Even though there are many claiming the end of the liberal world and transatlantic community, its resilience and the resilience of the two main organizations, proved throughout the years and various crises, shall not be underestimated. This even more as geopolitical competition between great powers may function as a possible stimulus for cohesion when confronted with a common threat.

\section{BIBLIOGRAPHY:}

ABRAMOWITZ, Michael J. Freedom in the World 2018. Democracy in Crisis. Freedom House, 2018.

ADLER, Emanuel, and BARNETT Michael. Security Communities. Cambridge, 1998.

BARBER, Lionel, FOY Henry, and BARKER Alex. "Vladimir Putin says liberalism has 'become obsolete'." Financial Times, 2019.

BOGZEANU, Cristina. "Rule of Law in the Context of the Double Blocking of 2021-2027 Multiannual Financial Framework and Next Generation EU." Edited by Centre for Defence and Security Strategic Studies. Strategic Impact ("Carol I" National Defence University) 77, no. 4 (2020b): 24-37.

BOYLE, Brendan. Confronting Russia's Continuing Geopolitical and Ideological Challenge. Draft Report. NATO Parliamentary Assembly, 2021.

Centre for Defence and Security Strategic Studies. Riscuri și amenințări de securitate la adresa României. Centre for Defence and Security Strategic Studies, „Carol I” National Defence University, Bucharest: "Carol” National Defence University Publishinghouse, 2021.

Comisia Europeană. "Rule of law mechanism." 2020.

EU Council. Long-term EU budget 2021-2027 and recovery package. 2020. https://www.consilium.europa.eu/en/policies/the-eu-budget/long-term-eu-budget-20212027/ (accessed 11 11, 2021).

EU Council. "Special meeting of the European Council (17, 18, 19, 20 and 21 July 2020) Conclusions." Brussels, 2020.

EU Global Strategy. "A Global Strategy for the European Union's Foreign and Security Policy." 2016.

European Commission and HR/VP. "EU-China - A Strategic Outlook, 12 March 2019." 2019.

- European Democracy Action Plan. 2021. https://ec.europa.eu/commission/presscorner/ detail/en/IP_20_2250 (accessed 11 11, 2021).

Freedom House. "Democracy Status." 2021.

Freedom House. "Democracy Status." 2020.

Freedom House. Nations in Transit 2021. The antidemocratic turn. Washington D.C.: Freedom House, 2021.

GALEOTTI, Mark. Controlling Chaos: How Russia Manages its Political War in Europe. European Council on Foreign Affairs, 2017.

LASCONJARIAS, Guillaume. Deterrence through Resilience: NATO, the Nations and the Challenges of Being Prepared. NATO Defence College., 2017.

LINDBERG, Staffan I. "Autocratization Turns Viral. Democracy Report 202." V-Dem Institute, University of Gothenburg, March 2021. 
MEARSHEIMER, John J. "Bound to Fail: The Rise and Fall of the Liberal International Order." Internationa Security 43, no. 4 (Spring 2019): 7-50.

MIROIU, Andrei, and Radu-Sebastian Ungureanu. Manual de Relații Internaționale. Iași: Polirom, 2006.

NATO 2030. "NATO 2030: United for a New Era. Analysis and Recommendations of the Reflection Group Appointed by NATO Secretary General." 2020.

NATO. "Commitment to enhance resilience issued by the Heads of State and Government participating in the meeting of the North Atlantic Council in Warsaw,." 2016.

NATO Strategic Communication Centre of Excellence. "NATO Strategic Communication Centre of Excellence." 2021.

NATO Strategic Concept. "Active Engagement, Modern Defence. Strategic Concept for the Defence and Security of the Members of the North Atlantic Treaty Organization Adopted by Heads of State and Government at the NATO Summit in Lisbon." 2010.

NATO. "The North Atlantic Treaty." 4 4, 1949. https://www.nato.int/cps/en/natohq/official_ texts_17120.htm (accessed 11 11, 2021).

Office of the Secretary of Defence - China. "Military and Security Developments involving the People's Republic of China 2021. Annual Report to Congress." 2021, 1.

OZAWA, Mark. "Russia and China: 'axis of convenience' or 'stable strategic partnership'?”." NATO Defence College Policy Brief, No. 16, 2019.

President of Russia. Vladimir Putin speech in the Meeting of the Valdai International Discussion Club. 2013. http://en.kremlin.ru/events/president/news/19243.

Reflection Group Appointed by the NATO Secretary General. "NATO 2030: United for a New Era." NATO, 2020.

SARCINSCHI, Alexandra. „Competiția pentru vaccin și resurse medicale: o nouă fațetă a luptei pentru putere pe scena internaţională.” Impact Strategic, 2020: 7-23.

STARLING, Clementine G. "Trump's NATO Policy 'Trending Positive." Atlantic Council (Atlantic Council), 2018.

TAMMEN, Ronald L., et al. Power Transitions: Strategies for the 21st Century. Ronald L. Tammen, Jacek Kugler, Douglas Lemke, Allan C. Stamm III, Mark Abdollahian, Carole Alsharabati, A.F.K. Organski, New York: Chatham House Publishers, Seven Bridges Press, 2000.

The Economist Intelligence Unit. Democracy Index 2020. In Sikness and In Health >. 2021.

The European Centre of Excellence for Countering Hybrid Threats. "The European Centre of Excellence for Countering Hybrid Threats." 2021.

The European Union. Consolidated Versions of the Treaty on the European Union and the Treaty on the Functioning of the European Union. Brussels, March 2010. 
United States Senate. "Putin's Assymetric Assault on Democracy in Russia and Europe: Implications for US National Security. A Minority Staff Report Prepared for the Use of the Committee of Foreign Relations." 2018.

Uniunea Europeană. Versiune Consolidată a Tratatului privind Uniunea Europeană și a Tratatului privind Funcționarea Uniunii Europene. Carta Drepturilor Fundamentale a Uniunii Europene. Uniunea Europeană, Belgium: Oficiul pentru Publicaţii al Uniunii Europene, 2010.

V-DEM. Autocratization Turns Viral. Democracy Report. University of Gothenburg, 2021.

WRIGHT, Thomas. "The Return to Gret-Powern Rivalry was Inevitable." The Atlantic, 2018. 